\title{
Size, weight, and diet of the invasive lionfish Pterois volitans (Linnaeus, 1758) on the southern coast of Veracruz, Gulf of Mexico
}

\section{Talla, peso y dieta del pez león invasor Pterois volitans (Linnaeus, 1758) en la costa sur de Veracruz, golfo de México}

\author{
Rosalía Aguilar-Medrano, Ma. Eugenia Vega-Cendejas* \\ Laboratorio de Taxonomía y Ecología de Peces, Centro de Investigación y de Estudios Avanzados del Instituto \\ Politécnico Nacional, Unidad Mérida, Antigua carretera a Progreso, km 6, CP 97310, Mérida, Yucatán, Mexico.
}

* Corresponding author. E-mail: maruvega@cinvestav.mx

\begin{abstract}
The invasion of the Indo-Pacific lionfish Pterois volitans has produced detrimental impacts on the regional biodiversity and fisheries of invaded ranges. To understand the effect this lionfish may have on the native fish communities, it is necessary to understand its feeding habits. The objectives of this study were to report new distribution records of P. volitans along the southern coast of Veracruz (México), to document the feeding habits of the collected specimens, and to determine if there was a relationship between the diet, size, and weight of those specimens. The density of $P$. volitans in our study area was low. Diet composition for this species consisted of bony fishes (95.40\%), crustaceans $(4.20 \%)$, and mollusks $(0.36 \%)$. Lionfish size and weight were positively correlated. We did not find statistical differences between the diet and the size/weight groupings; however, the smaller specimens seemingly had a more varied diet than the larger specimens.
\end{abstract}

Key words: invasive species, Gulf of Mexico, diet composition, stomach contents.

RESUMen. La invasión del pez león del Indo-Pacífico Pterois volitans ha producido impactos perjudiciales sobre la biodiversidad regional y las pesquerías de zonas invadidas. Para comprender el efecto que puede tener el pez león en las comunidades nativas, es necesario conocer sus hábitos alimenticios. Los objetivos de este estudio fueron documentar nuevos registros de distribución de $P$. volitans a lo largo de la costa sur de Veracruz (México), documentar los hábitos alimenticios de los especímenes recolectados y determinar si existía una relación entre la dieta, la talla y el peso de estos especímenes. La densidad de $P$. volitans en nuestra área de estudio fue baja. La composición de la dieta de esta especie consistió en peces óseos $(95.40 \%)$, crustáceos $(4.20 \%)$ y moluscos $(0.36 \%)$. La talla y el peso del pez león estuvieron positivamente correlacionados. No encontramos diferencias estadísticas entre la dieta y los grupos de talla/peso; sin embargo, los especímenes de menor talla, aparentemente, tuvieron una dieta más variada que los especímenes de mayor talla.

Palabras clave: especies invasoras, golfo de México, composición de la dieta, contenido estomacal.

\section{INTRODUCTION}

The spreading of invasive species across marine ecosystems has had extreme effects on regional biodiversity and production of fishery resources (Green et al. 2012, Albins and Hixon 2013). The invasion of the Indo-Pacific lionfish Pterois volitans (Linnaeus 1758) across the western Atlantic and the Caribbean has produced detrimental effects on native species. In the Bahamas, this species reduced the biomass of 42 small-bodied fish species by $65 \%$ in 2 years (Green et al. 2012). The success of P. volitans is partly attributed to its voracity, varied diet, and high consumption rates (Morris and Akins 2009, Layman and Allgeier 2012). In its native range the lionfish, a reef fish, feeds primarily on small fishes and invertebrates (Harmelin-Vivien and Bouchon 1976); however, in invaded ranges the lionfish has been reported to exhibit opportunistic behavior, as it has been found in unexpected locations, such as temperate coasts (Aguilar-Medrano 2017) or mangroves (Barbour et al. 2010), showing opportunistic generalist diets largely

\section{INTRODUCCIÓN}

La propagación de especies invasoras en los ecosistemas marinos ha tenido efectos extremos sobre la biodiversidad regional y la producción de recursos pesqueros (Green et al. 2012, Albins y Hixon 2013). La invasión del pez león del Indo-Pacífico Pterois volitans (Linnaeus 1758) a través del Atlántico occidental y el Caribe ha producido efectos perjudiciales en las especies nativas. En las Bahamas, esta especie redujo en un $65 \%$ la biomasa de 42 especies de peces de talla pequeña en 2 años (Green et al. 2012). El éxito del pez león se atribuye, en parte, a su voracidad, su amplia dieta y sus altas tasas de consumo (Morris y Akins 2009, Layman y Allgeier 2012). En su área de distribución nativa, el pez león, un pez de arrecife, se alimenta principalmente de pequeños peces e invertebrados (Harmelin-Vivien y Bouchon 1976); sin embargo, algunos estudios han reportado que, en zonas invadidas, el pez león tiene un comportamiento oportunista, pues se ha encontrado en lugares inesperados como costas templadas (Aguilar-Medrano 2017) o manglares (Barbour et al. 2010), 
based on bony fishes and crustaceans (Morris and Akins 2009, Layman and Allgeier 2012) and some mollusks (Arredondo-Chávez et al. 2016).

Since $P$. volitans was first reported in the Veracruz Reef System National Park (VRSNP) in 2012 (SantanderMonsalvo et al. 2012), local authorities have been reporting its presence in the park. Despite ongoing reports and with the exception of the study by Montoya-Mendoza et al. (2017), who analyzed the parasites of P. volitans in this area, no studies on the biology of the species in this new environment have been published. Therefore, in order to produce novel information on $P$. volitans, the present study tested sampling at different depths and times on a silt flat south of the VRSNP with a fishing gear that allowed collecting representative samples of all sizes. The objectives of this study were (1) to report new distribution records of P. volitans in the Gulf of Mexico, (2) to document the feeding habits of collected specimens to better understand the impact $P$. volitans may have on the native community, and (3) to determine if there was any variation in the diet of specimens with size and weight.

\section{MATERIALS AND METHODS}

\section{Sampling design}

Five stations located along the coast of Veracruz, south of the VRSNP, were sampled in March 2018 (Fig. 1), covering latitudes from $20^{\circ} 38^{\prime} \mathrm{N}$ to $20^{\circ} 48^{\prime} \mathrm{N}$, longitudes from $96^{\circ} 51^{\prime} \mathrm{W}$ to $96^{\circ} 56^{\prime} \mathrm{W}$, and depths from 45 to $71 \mathrm{~m}$. All stations had a fine and thick silty substratum. Sampling was designed to test for different times in a day, with 2 samplings in the morning (station 4, 6:47 AM; station 2, 8:46 AM), 2 in the afternoon (station 1, 12:48 PM; station 3, 1:58 PM), and 1 at night (station 5, 8:00 PM). All samples were collected using a shrimp trawl net $(18.3 \mathrm{~m}$ in length, $3.4 \mathrm{~cm}$ mesh size), which was towed for 20 to $30 \mathrm{~min}$ at a constant speed of 2.5 knots. The collected specimens were frozen and identified to species level (Schultz 1986, Labastida-Estrada et al. 2019).

\section{Stomach content analyses}

The feeding habits of specimens were determined by analyzing stomach contents. All specimens were measured (standard length, SL) and weighed (wet weight). The digestive tract of each specimen was removed and weighed, and stomach contents were all extracted and identified to the lowest possible taxonomic unit. The contribution of each prey taxon to the overall diet was assessed using 3 relative metrics. Of the three, the percent composition by weight takes into account the wet weight of each component, and the total weight of a food category is then expressed as a percentage of the overall weight of stomach contents (VegaCendejas et al. 1994). The percent composition by area was con una dieta generalista oportunista basada principalmente en peces óseos y crustáceos (Morris y Akins 2009, Layman y Allgeier 2012) y algunos moluscos (Arredondo-Chávez et al. 2016).

Desde que $P$. volitans fue reportada por primera vez en el Parque Nacional del Sistema Arrecifal de Veracruz (PNSAV) en 2012 (Santander-Monsalvo et al. 2012), las autoridades locales han estado reportando su presencia en el parque. A pesar de los reportes continuos y a excepción del estudio de Montoya-Mendoza et al. (2017), quienes analizaron los parásitos de $P$. volitans en esta área, no se han publicado estudios sobre la biología de la especie en este nuevo entorno. Por lo tanto, para producir información novedosa de $P$. volitans, el presente estudio probó muestreos a diferentes profundidades y horas en un sustrato de limo al sur del PNSAV utilizando un arte de pesca que permitiera recolectar muestras representativas de todas las tallas. Los objetivos de este estudio fueron (1) informar sobre nuevos registros de distribución de $P$. volitans en el golfo de México, (2) documentar los hábitos alimenticios de los especímenes recolectados para comprender mejor el impacto que $P$. volitans puede tener en la comunidad nativa y (3) determinar si había una variación en la dieta de los especímenes según el tamaño y el peso.

\section{MATERIALES Y MÉTODOS}

\section{Diseño de muestreo}

Se muestrearon 5 estaciones a lo largo de la costa de Veracruz, al sur del PNSAV, en marzo de 2018 (Fig. 1), las cuales cubrieron latitudes desde $20^{\circ} 38^{\prime} \mathrm{N}$ hasta $20^{\circ} 48^{\prime} \mathrm{N}$, longitudes desde $96^{\circ} 51^{\prime} \mathrm{W}$ hasta $96^{\circ} 56^{\prime} \mathrm{W}$ y profundidades de 45 a $71 \mathrm{~m}$. Todas las estaciones presentaron un sustrato de limo fino y grueso. El muestreo se diseñó para evaluar diferentes horas de un día, con 2 muestreos realizados en la mañana (estación 4, 6:47 AM; estación 2, 8:46 AM), 2 en la tarde (estación 1, 12:48 PM; estación 3, 1:58 PM) y 1 en la noche (estación 5, 8:00 PM). Todas las muestras se recolectaron utilizando una red de arrastre camaronera (18.3 m de largo, $3.4 \mathrm{~cm}$ de tamaño de malla), la cual fue arrastrada por lapsos de 20 a 30 min a una velocidad constante de 2.5 nudos. Los especímenes recolectados fueron congelados e identificados a nivel de especie (Schultz 1986, Labastida-Estrada et al. 2019).

\section{Análisis de contenido estomacal}

Los hábitos alimenticios de los especímenes recolectados se determinaron mediante análisis de contenido estomacal. Todas los especímenes recolectados fueron medidos (longitud estándar, LS) y pesados (peso húmedo). El tracto digestivo de cada ejemplar fue retirado y pesado, y todo el contenido estomacal fue extraído e identificado al taxón más bajo posible. La contribución de cada taxón presa a la dieta 


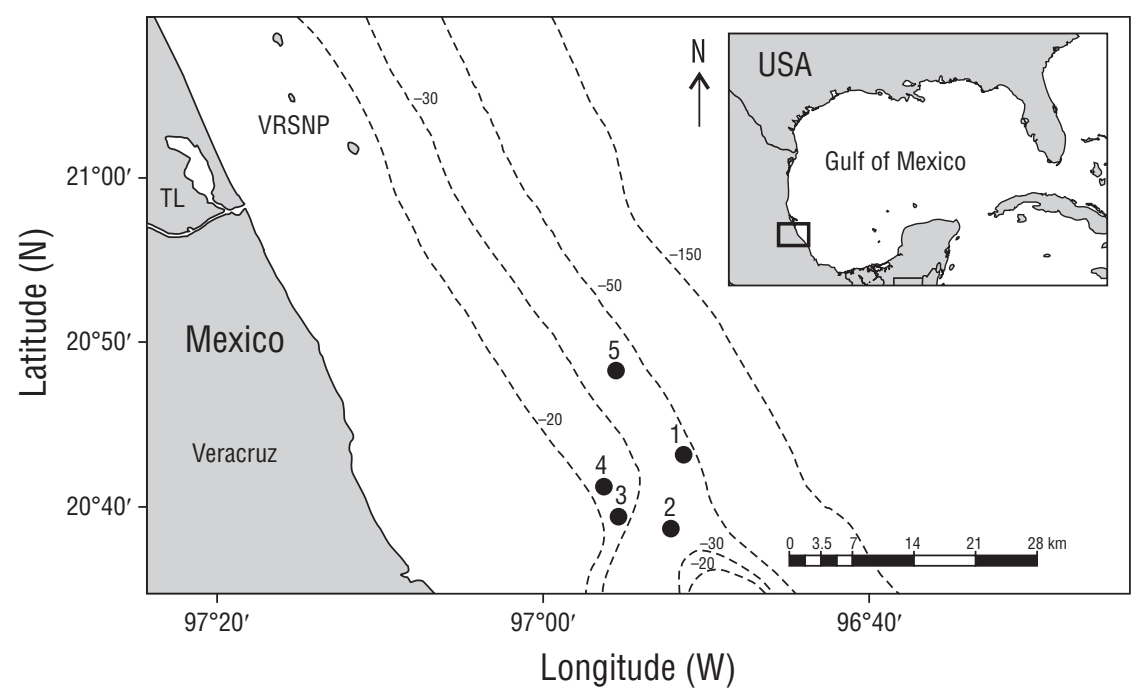

Figure 1. Map showing the 5 oceanographic sampling stations (filled circles) along the southern coast of Veracruz, Gulf of Mexico. Dashed isolines indicate depth in meters. VRSNP: Veracruz Reef System National Park; TL: Tampamachoco Lagoon.

Figura 1. Mapa que muestra las estaciones oceanográficas de muestreo a lo largo de la costa sur de Veracruz, golfo de México. Las líneas discontinuas indican la profundidad en metros. VRSNP: Parque Nacional del Sistema Arrecifal de Veracruz; TL: laguna Tampamachoco.

used when stomach contents were constituted of very small prey whose weight was not possible to record with an analytical balance; this method provides a more representative measure of biomass and can be applied to all food components (Canto-Maza and Vega-Cendejas 2007). The percent frequency of occurrence takes into account the number of times a prey appears in the stomach contents of a group of fish and is expressed as a percentage (Canto-Maza and Vega-Cendejas 2007).

\section{Size, weight, and diet}

Since the size and weight variables did not meet the normality criteria, we used non-parametric methods. The relationship between the SL and weight of specimens and the weight of the digestive tract was analyzed by Spearman's D correlation (Press et al. 1992). Then, to make a size/weight group (SWG) classification, a cluster analysis based on the size and weight of specimens was performed by the unweighted pair group method with arithmetic mean (UPGMA) using the Euclidian distance. UPGMA is an agglomerative hierarchical clustering method that constructs a tree that reflects the structure present in a pairwise similarity matrix (Sokal and Michener 1958). The obtained grouping was analyzed via a permutational multivariate analysis of variance (PERMANOVA) to test for significant differences between 2 or more groups (Anderson 2001). PERMANOVA was also used to determine if there were differences in the diet across SWGs using the information gathered from prey items, such as occurrence, area, and weight. All statistical analyses were done using PAST 3.20 (Hammer et al. 2001). general se evaluó utilizando 3 métricas relativas. De estas tres, el porcentaje de composición por peso toma en cuenta el peso húmedo de los componentes, y el peso total de una categoría alimenticia se expresa, entonces, como un porcentaje del peso total del contenido estomacal (Vega-Cendejas et al. 1994). El porcentaje de composición por área fue utilizado cuando el contenido estomacal estuvo constituido por presas muy pequeñas cuyo peso no fue posible registrar en una balanza analítica; este método proporciona una medida más representativa de la biomasa y se puede aplicar a todos los componentes alimenticios (Canto-Maza y Vega-Cendejas 2007). El porcentaje de frecuencia de ocurrencia toma en cuenta el número de veces que aparece una presa en el contenido estomacal de un grupo de peces, y se expresa como un porcentaje (Canto-Maza y Vega-Cendejas 2007).

\section{Talla, peso y dieta}

Dado que las variables de talla y peso no cumplieron los criterios de normalidad, utilizamos métodos no paramétricos. La relación entre la LS y el peso de las muestras y el peso del tracto digestivo se analizó mediante la correlación $\mathrm{D}$ de Spearman (Press et al. 1992). Luego, para producir una clasificación de grupo de talla/peso (GTP), se llevó a cabo un análisis de conglomerados basado en la talla y el peso de los especímenes mediante el método de grupo de pares no ponderados con media aritmética (UPGMA, por sus siglas en inglés) utilizando la distancia euclidiana. UPGMA es un método de agrupamiento jerárquico aglomerativo que construye un árbol que refleja la estructura presente en una matriz de similitud por pares (Sokal y Michener 1958). La agrupación obtenida se analizó mediante un análisis de varianza 


\section{RESULTS}

A total of 17 specimens were collected, with SLs ranging from 6.9 to $40.2 \mathrm{~cm}$ and weights from 7.6 to $847.7 \mathrm{~g}$. All specimens were confirmed as P. volitans (D: XIII-12, A: III-8). Most specimens were collected at station 5, the nocturnal sampling station (Table 1).

\section{Diet}

Three main taxonomic groups were identified in the diet of $P$. volitans, the phylum Mollusca, the subphylum Crustacean, and the superclass Osteichthyes, being the bony fishes the dominant items (Table 2). Of the 32 classified items, 21 were bony fishes, 9 crustaceans, and 2 mollusks. The values for percent composition of prey items by area and by weight were highly similar; approximately $95.40 \%$ of the total composition by area and weight was made up of bony fishes, whereas crustaceans made up approximately $4.20 \%$ and mollusks approximately $0.36 \%$ of total composition (Table 2). múltiple no paramétrica (PERMANOVA), una prueba de diferencia significativa entre 2 o más grupos (Anderson 2001). El PERMANOVA se usó también para determinar si existían diferencias en la dieta entre los GTP en función de la información de las entidades alimentarias, como la ocurrencia, el área y el peso. Todos los análisis estadísticos se realizaron con PAST 3.20 (Hammer et al. 2001).

\section{Resultados}

Se recolectó un total de 17 especímenes, con LS entre 6.9 y $40.2 \mathrm{~cm}$ y pesos de 7.6 a 847.7 g. Se confirmó que los especímenes recolectados pertenecían a la especie $P$. volitans (D: XIII-12, A: III-8). La mayoría de los especímenes fueron recolectados en la estación 5, la estación de muestreo nocturno (Tabla 1).

\section{Dieta}

Se identificaron 3 grupos taxonómicos principales en la dieta de $P$. volitans, el filo Mollusca, el subfilo Crustacea y la

Table 1. Geographic location and sampling specifications for the 5 sampling stations. Depth refers to the initial and final towing depths. The size (FS, standard length) and weight (FW) of the 17 Pterois volitans specimens are also given.

Tabla 1. Ubicación geográfica y especificaciones de muestreo para las 5 estaciones de muestreo. La profundidad se refiere a la profundidad inicial y final de dragado. También se muestran la talla (FS, longitud estándar) y el peso (FW) de los 17 especímenes de Pterois volitans.

\begin{tabular}{|c|c|c|c|c|c|c|c|c|}
\hline \multirow[b]{2}{*}{ Station } & \multirow[b]{2}{*}{ Latitude } & \multirow[b]{2}{*}{ Longitude } & \multicolumn{2}{|c|}{ Depth (m) } & \multirow[b]{2}{*}{ Time } & \multirow[b]{2}{*}{ Specimen } & \multirow{2}{*}{$\begin{array}{c}\mathrm{FS} \\
(\mathrm{cm})\end{array}$} & \multirow{2}{*}{$\begin{array}{l}\text { FW } \\
(\mathrm{g})\end{array}$} \\
\hline & & & Initial & Final & & & & \\
\hline \multirow[t]{2}{*}{2} & $20^{\circ} 38^{\prime} 39.36^{\prime \prime}$ & $96^{\circ} 52^{\prime} 11.04^{\prime \prime}$ & 57 & 61 & 8:46 AM & 2 & 17.5 & 189.30 \\
\hline & & & & & & 3 & 21.0 & 320.00 \\
\hline \multirow[t]{2}{*}{3} & $20^{\circ} 39^{\prime} 23.10^{\prime \prime}$ & $96^{\circ} 55^{\prime} 22.68^{\prime \prime}$ & 46 & 45 & 1:58 PM & 5 & 31.0 & 418.30 \\
\hline & & & & & & 6 & 40.2 & 847.70 \\
\hline 4 & $20^{\circ} 41^{\prime} 13.38^{\prime \prime}$ & $96^{\circ} 56^{\prime} 16.02^{\prime \prime}$ & 45 & 43 & 6:47 AM & 7 & 40.3 & 847.60 \\
\hline \multirow[t]{7}{*}{5} & $20^{\circ} 48^{\prime} 16.68^{\prime \prime}$ & $96^{\circ} 55^{\prime} 33.90^{\prime \prime}$ & 63 & 67 & 8:00 PM & 8 & 10.2 & 17.63 \\
\hline & & & & & & 12 & 23.2 & 160.03 \\
\hline & & & & & & 13 & 25.0 & 201.10 \\
\hline & & & & & & 14 & 27.0 & 269.40 \\
\hline & & & & & & 15 & 28.6 & 297.50 \\
\hline & & & & & & 16 & 29.4 & 424.90 \\
\hline & & & & & & 17 & 38.0 & 831.10 \\
\hline
\end{tabular}




\section{Size, weight, and diet}

Correlation was strongest between the SL and weight of specimens $(r=76.5, P<0.000)$, followed by the correlation between the weight of specimens and the weight of the digestive tracts $(r=146.5, P<0.001)$ and the correlation between the SL of specimens and the weight of the digestive tracts $(r=238, P<0.005)$. With data on specimen SL and weight, the UPGMA produced 3 statistically independent groups $(F=$ 120.6, $P<0.000)$ : SWG1, which grouped 8 of the smallest and lightest specimens $(\mu \mathrm{SL}=17.74 \mathrm{~cm}$, weight $=112.4 \mathrm{~g})$; SWG2, which grouped 6 specimens with mean size/weight $(\mu \mathrm{SL}=26.55 \mathrm{~cm}$, weight $=328.55 \mathrm{~g})$; and SWG3, which grouped 3 of the largest and heaviest specimens ( $\mu$ SL $=$ $39.47 \mathrm{~cm}$, weight $=842.17 \mathrm{~g}$ ). The comparison of frequency superclase Osteichthyes, siendo los peces óseos las entidades alimentarias dominantes (Tabla 2). De las 32 entidades clasificadas, 21 fueron peces óseos, 9 crustáceos y 2 moluscos. Los valores del porcentaje de la composición por área y por peso de las entidades alimentarias fueron muy similares; aproximadamente el $95.40 \%$ de la composición total por área y por peso fue de peces óseos, mientras que los crustáceos ocuparon aproximadamente el $4.20 \%$ y los moluscos aproximadamente el $0.36 \%$ de la composición total (Tabla 2).

\section{Talla, peso y dieta}

La correlación fue más fuerte entre la LS y el peso de los especímenes $(r=76.5, P<0.000)$, seguida de la correlación entre el peso de los especímenes y el peso del tractoigestivo

Table 2. Stomach contents by size/weight group (SWG) of Pterois volitans specimens. FO: frequency of occurrence; PA: percent composition by area; PW: percent composition by weight.

Tabla 2. Contenido estomacal por grupo de talla/peso (SWG) de los especímenes de Pterois volitans. FO: frecuencia de ocurrencia; PA: porcentaje de composición por área; PW: porcentaje de composición por peso.

\begin{tabular}{|c|c|c|c|c|c|}
\hline Group number & Prey Item & & $\mathrm{FO}(\%)$ & $\mathrm{PA}\left(\mathrm{cm}^{2}\right)$ & $\mathrm{PW}(\mathrm{g})$ \\
\hline \multirow[t]{10}{*}{ SWG1 (8 specimens) } & \multirow[t]{3}{*}{ Fish } & Osteichthyes & 43.75 & 79.36 & 76.49 \\
\hline & & Synodontidae & 6.25 & 1.49 & 1.49 \\
\hline & & Serranus spp. & 6.25 & 9.40 & 13.94 \\
\hline & \multirow[t]{6}{*}{ Crustacea } & Crustacea & 6.25 & 1.66 & 0.83 \\
\hline & & Decapoda & 6.25 & 1.33 & 0.67 \\
\hline & & Farfantepenaeus spp. & 6.25 & 1.79 & 1.65 \\
\hline & & Portunus spp. & 6.25 & 3.10 & 2.41 \\
\hline & & Raninoides spp. & 6.25 & 0.60 & 0.11 \\
\hline & & Sicyonia spp. & 6.25 & 0.86 & 1.35 \\
\hline & Mollusca & Bivalvia & 6.25 & 0.41 & 1.05 \\
\hline \multirow[t]{6}{*}{ SWG2 (6 specimens) } & \multirow[t]{4}{*}{ Fish } & Osteichthyes & 50.00 & 38.55 & 19.23 \\
\hline & & Synodontidae & 8.33 & 2.91 & 2.48 \\
\hline & & Serranus spp. & 8.33 & 0.90 & 0.22 \\
\hline & & Scyacium gunteri & 8.33 & 56.01 & 77.02 \\
\hline & Crustacea & Brachyura & 16.67 & 1.28 & 0.80 \\
\hline & Mollusca & Gastropoda & 8.33 & 0.36 & 0.24 \\
\hline \multirow[t]{2}{*}{ SWG3 (3 specimens) } & Fish & Osteichthyes & 75.00 & 84.17 & 78.50 \\
\hline & Crustacea & Sicyonia spp. & 25.00 & 15.83 & 21.50 \\
\hline \multirow[t]{3}{*}{ Total (17 specimens) } & Fish & & 65.63 & 94.96 & 95.88 \\
\hline & Crustacea & & 28.15 & 4.69 & 3.75 \\
\hline & Mollusca & & 6.26 & 0.35 & 0.37 \\
\hline
\end{tabular}


of occurrence, area, and weight between SWGs showed no significant differences $(F=1.275, P=0.285$; Fig. 2).

\section{Discussion}

Our study corroborates the results of Morris and Akins (2009), Layman and Allgeier (2012), and Arredondo-Chávez et al. (2016), which indicate that the diet of lionfish in an invaded range is largely composed of bony fishes, crustaceans, and mollusks, although we found mollusks in the diet of only SWG1. In the diet contents of $P$. volitans, we found fishes belonging to the genus Serranus, which in this area comprises 6 reef-associated species, the fish species Scyacium gunteri, which is a bottom dweller unassociated with reefs (Robertson and van Tassell 2019), and hard-shelled organisms belonging to the infraorder Brachyura and the classes Bivalvia and Gastropoda. We did not find differences in the diets between SWGs; however, it was clear that SWG1 had the more diverse diet.

According to our study, the highest $P$. volitans density was found at station 5, the one closest to the VRSNP, which could indicate that the closer the area to the reef the higher the density. Station 5, however, was only sampled at night and the high density there could also just be a corroboration of the
( $r=146.5, P<0.001)$ y la correlación entre la LS de los especímenes y el peso del tracto digestivo $(r=238, P<0.005)$. Con los datos de la LS y el peso de los especímenes, el UPGMA produjo 3 grupos estadísticamente independientes $(F=120.6, P<0.000)$ : GTP1, el cual agrupó a 8 de los especímenes más pequeños y livianos $(\mu \mathrm{LS}=17.74 \mathrm{~cm}$, peso $=$ $112.4 \mathrm{~g}$ ); GTP2, el cual agrupó a 6 especímenes de talla/ peso medio $(\mu \mathrm{LS}=26.55 \mathrm{~cm}$, peso $=328.55 \mathrm{~g})$; y GTP3, el cual agrupo a 3 de los especímenes más grandes y pesados $(\mu \mathrm{LS}=39.47 \mathrm{~cm}$, peso $=842.17 \mathrm{~g})$. La comparación de la frecuencia de ocurrencia, el área y el peso entre los GTP no mostró diferencias significativas $(F=1.275, P=0.285$; Fig. 2).

\section{Discusión}

Nuestro estudio corrobora los resultados de Morris y Akins (2009), Layman y Allgeier (2012) y ArredondoChávez et al. (2016), que indican que la dieta del pez león en su ámbito invadido se basa principalmente en peces óseos, crustáceos y moluscos, aunque nosotros encontramos moluscos en la dieta de solo el GTP1. En el contenido de la dieta de $P$. volitans encontramos peces del género Serranus, que en esta área presenta 6 especies asociadas a
SWG1

$(17.74 \mathrm{~cm}, 112.4 \mathrm{~g})$

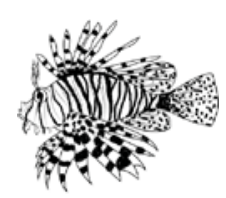

SWG2

$(26.55 \mathrm{~cm}, 328.55 \mathrm{~g})$
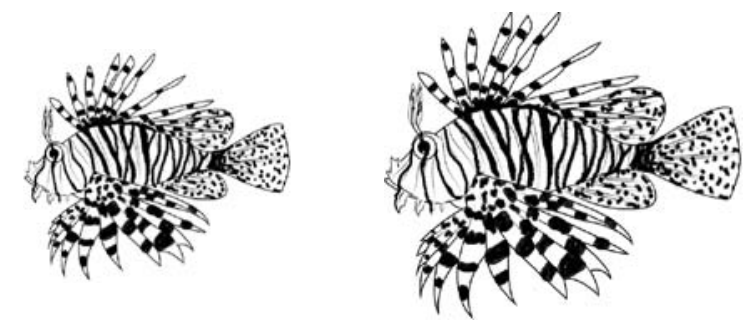

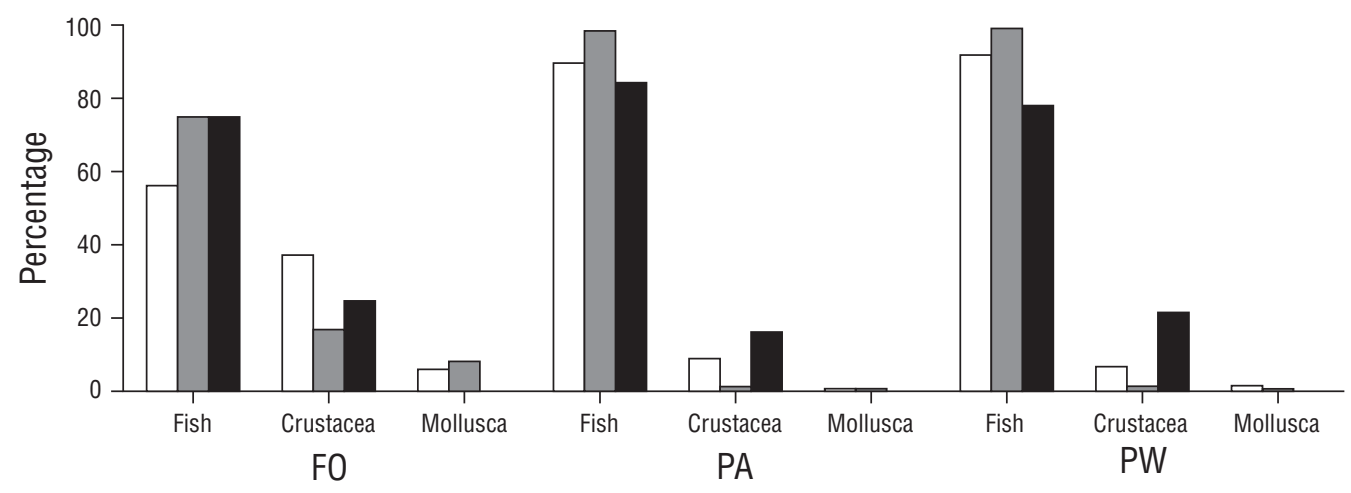

Figure 2. Main food categories in the diet of the lionfish Pterois volitans sampled along the southern coast of Veracruz by size/weight groups (SWG). Mean size and weight values are given in parentheses for each group. FO: frequency of occurrence; PA: percent composition by area; PW: percentage composition by weight.

Figura 2. Categorías alimenticias principales en la dieta del pez león Pterois volitans muestreado a lo largo de la costa sur de Veracruz por grupos de talla/peso (SWG). Los valores medios de talla y peso para cada grupo se muestran en paréntesis. FO: frecuencia de ocurrencia; PA: composición por área; PW: porcentaje de composición por peso. 
Aguilar-Medrano et al.: Size, weight, and diet of the lionfish Pterois volitans

nocturnal habits of the lionfish (Myers 1991). Our results indicate low lionfish density in the study area, as we captured 1 to 10 specimens per station in each trawl, which covered an area of approximately $22,715 \mathrm{~m}^{2}$. In our study we tried testing the use of a shrimp trawl net with a small mesh size to capture lionfish specimens in a wide range of sizes. Although we achieved the objective, this methodology is useful only for flat bottoms, away from the reefs.

The experience during these years of the invasion of P. volitans in the Gulf of Mexico and the Caribbean made it clear that efforts must be directed to control lionfish populations, as eradication seems unfeasible (Albins and Hixon 2013). It is important to produce information that reveals how this species interacts within an ecosystem in order to propose effective plans to buffer its negative effects. Trophic data can help us anticipate its arrival by directing conservation efforts to protect the key species found in its diet. Trophic analyses can help determine vulnerable life stages given the specific dietary needs, and control efforts can therefore be more specific by focusing on those life stages. The present study was a first attempt to understand the relation between the size, weight, and diet of the invasive lionfish $P$. volitans on the southern coast of Veracruz, Mexico.

\section{ACKNOWLEDGMENTS}

This research was funded by the Mexican National Council for Science and Technology-Mexican Ministry of Energy-Hydrocarbon Fund project (no. 201441). It is a contribution of the Gulf of Mexico Research Consortium. We acknowledge the request made by PEMEX to the Hydrocarbon Fund to address the environmental effects of oil spills in the Gulf of Mexico. We are grateful to Mirella Hernández, Ariel Chi, Maria Blanqueto, and Alex Acosta for their technical support and to the editor and the reviewers for their suggestions, which enriched the manuscript.

\section{REFERENCES}

Aguilar-Medrano R. 2017. Peces: Guía de Campo de la Laguna Madre, Tamaulipas. Ciudad Victoria (Mexico): Universidad Autónoma de Tamaulipas.

Albins MA, Hixon MA. 2013. Worst case scenario: potential longterm effects of invasive predatory lionfish (Pterois volitans) on Atlantic and Caribbean coral-reef communities. Environ Biol Fish. 96:1151-1157. https://doi.org/10.1007/s10641-011-9795-1

Anderson MJ. 2001. A new method for non-parametric multivariate analysis of variance. Austral Ecol. 26(1):32-46. https://doi.org/10.1111/j.1442-9993.2001.01070.pp.x

Arredondo-Chávez AT, Sánchez-Jimenez JA, Ávila-Morales OG, Torres-Chávez P, Herrerias-Diego Y, Medina-Nava M, Madrigal-Guridi X, Campos-Mendoza A, DomínguezDomínguez O, Caballero-Vázquez JA. 2016. Spatio-temporal variation in the diet composition of red lionfish, Pterois volitans (Actinopterygii: Scorpaeniformes: Scorpaenidae), in the Mexican Caribbean: insights into the ecological effect of the alien invasion. Acta Ichthyol Piscat. 46(3):185-200.

https://doi.org/10.3750/AIP2016.46.3.03 arrecifes, peces de la especie Scyacium gunteri, que es un pez no asociado a los arrecifes que habita el fondo marino (Robertson y van Tassell 2019), y organismos de caparazón duro del infraorden Brachyura y las clases Bivalvia y Gastropoda. No encontramos diferencias en las dietas entre los GTP; sin embargo, fue evidente que el GTP1 presentó la dieta más diversa.

De acuerdo con nuestro estudio, la densidad más alta de $P$. volitans se encontró en la estación 5 , la más cercana al PNSAV, lo que podría indicar que cuanto más cerca el área del arrecife más alta la densidad. Sin embargo, la estación 5 se muestreó solo en la noche, y la alta densidad que ahí se encontró podría ser una corroboración de los hábitos nocturnos del pez león (Myers 1991). Nuestros resultados indican una baja densidad del pez león en el área de estudio, pues capturamos de 1 a 10 especímenes por estación en cada arrastre, que cubrió aproximadamente un área de $22,715 \mathrm{~m}^{2}$. En nuestro estudio intentamos probar utilizar una red camaronera de arrastre con un tamaño de malla pequeño para capturar especímenes de pez león en una amplia gama de tallas. Aunque logramos el objetivo, esta metodología solo es útil en fondos planos, lejos de los arrecifes.

La experiencia durante estos años de la invasión de $P$. volitans en el golfo de México y el Caribe dejó en claro que los esfuerzos deben dirigirse a controlar las poblaciones del pez león ya que la eliminación parece inviable (Albins y Hixon 2013). Es importante producir información que indique la forma en que esta especie interactúa en un ecosistema para proponer planes efectivos para amortiguar sus efectos negativos. Los datos tróficos pueden ayudarnos a anticipar su llegada dirigiendo los esfuerzos de conservación a especies clave que se encuentran en su dieta. Los análisis tróficos hacen posible determinar etapas de vida vulnerables del pez león debido a necesidades alimentarias específicas, y de esta manera, los esfuerzos de control pueden ser más específicos al centrarse en esas etapas. El presente estudio fue un primer intento para comprender la relación entre la talla, el peso y la dieta del pez león invasor $P$. volitans en la costa sur de Veracruz, México.

\section{Agradecimientos}

Esta investigación fue financiada por el proyecto conjunto del Consejo Nacional de Ciencia y Tecnología de México y el Fondo de Hidrocarburos del Ministerio de Energía de México (no. 201441). Es una contribución del Consorcio de Investigación del Golfo de México. Reconocemos la solicitud específica de PEMEX al Fondo de Hidrocarburos para abordar los efectos ambientales de los derrames de petróleo en el golfo de México. Agradecemos a Mirella Hernández, Ariel Chi, Maria Blanqueto y Alex Acosta su apoyo técnico $\mathrm{y}$ al editor $\mathrm{y}$ los revisores sus sugerencias, que enriquecieron el manuscrito. 
Barbour AB, Montgomery ML, Adamson AA, Díaz-Ferguson E, Silliman BR. 2010. Mangrove use by the invasive lionfish Pterois volitans. Mar Ecol Prog Ser. 401:291-294. https://doi.org/10.3354/meps08373

Canto-Maza WG, Vega-Cendejas ME. 2007. Distribución, abundancia y preferencias alimenticias del pez sapo Opsanus phobetron (Batrachoididae) en la laguna costera de Chelem, Yucatán, México. Rev Biol Trop. 55(3-4):979-988.

Green SJ, Akins JL, Maljković A, Côté IM. 2012. Invasive lionfish drive Atlantic coral reef fish declines. PlOS One. 7(3):e32596. https://doi.org/10.1371/journal.pone.0032596

Hammer Ø, Harper DAT, Ryan PD. 2001. PAST: Paleontological Statistics software package for education and data analysis. Palaeontol Electron. 4(1):1-9.

Harmelin-Vivien ML, Bouchon C. 1976. Feeding behavior of some carnivorous fishes (Serranidae and Scorpaenidae) from Tuléar (Madagascar). Mar Biol. 37:329-340. https://doi.org/10.1007/BF00387488

Labastida-Estrada E, Machkour-M'Rabet S, Carrillo L, Hénaut Y, Castelblanco-Martínez DN. 2019. Genetic structure of Mexican lionfish populations in the southwest Gulf of Mexico and the Caribbean Sea. PLOS ONE. 14(10):e0222997. https://doi.org/10.1371/journal.pone.0222997

Layman CA, Allgeier JE. 2012. Characterizing trophic ecology of generalist consumers: a case study of the invasive lionfish in The Bahamas. Mar. Ecol. Prog. Ser. 448:131-141. https://doi.org/10.3354/meps09511

Montoya-Mendoza J, Camarena-Luhrs T, Castañeda-Chávez MR, Lango-Reynoso F. 2017. Helminth Parasites of Red Lionfish, Pterois volitans from the Veracruz Coral Reef System, Mexico, Southern Gulf of Mexico. J Agr Sci. 9(11):30-33. https://doi.org/10.5539/jas.v9n11p30
Morris JA Jr, Akins JL. 2009. Feeding ecology of invasive lionfish (Pterois volitans) in the Bahamian archipelago. Environ Biol Fish. 86:389. https://doi.org/10.1007/s10641-009-9538-8

Myers RF. 1991. Micronesian Reef Fishes: A Practical Guide to the Identification of the Coral Reef Fishes of the Tropical Central and Western Pacific. 2nd ed. Barrigada (Guam): Coral Graphics

Press WH, Teukolsky SA, Vetterling WT, Flannery BP. 1992. Numerical Recipes in C: The Art of Scientific Computing. 2nd ed. Cambridge: Cambridge University Press.

Robertson DR, van Tassell J. 2019. Shorefishes of the Greater Caribbean: online information system. Version 2.0. Balboa (Panama): Smithsonian Tropical Research Institute; accessed 2019 Nov. https://biogeodb.stri.si.edu/caribbean/en/pages.

Santander-Monsalvo J, López-Huerta I, Aguilar-Perera A, TuzSulub A. 2012. First record of the red lionfish (Pterois volitans [Linnaeus, 1758]) off the coast of Veracruz, Mexico. BioInvasions Rec. 1(2):121-124. https://doi.org/10.3391/bir.2012.1.2.07

Sokal RR, Michener CD. 1958. A statistical method for evaluating systematic relationships. Kans Univ Sci Bull. 38(22):1409-1438.

Schultz ET. 1986. Pterois volitans and Pterois miles: Two valid species. Copeia. 3:686-690. https://doi.org/10.2307/1444950

Vega-Cendejas ME, Hernández M, Arreguin-Sánchez F. 1994. Trophic interrelations in a beach seine fishery from the northwestern coast of the Yucatan peninsula, Mexico. J Fish Biol. 44(4):647-659.

https://doi.org/10.1111/j.1095-8649.1994.tb01241.x

Received May 2019, accepted February 2020. 